
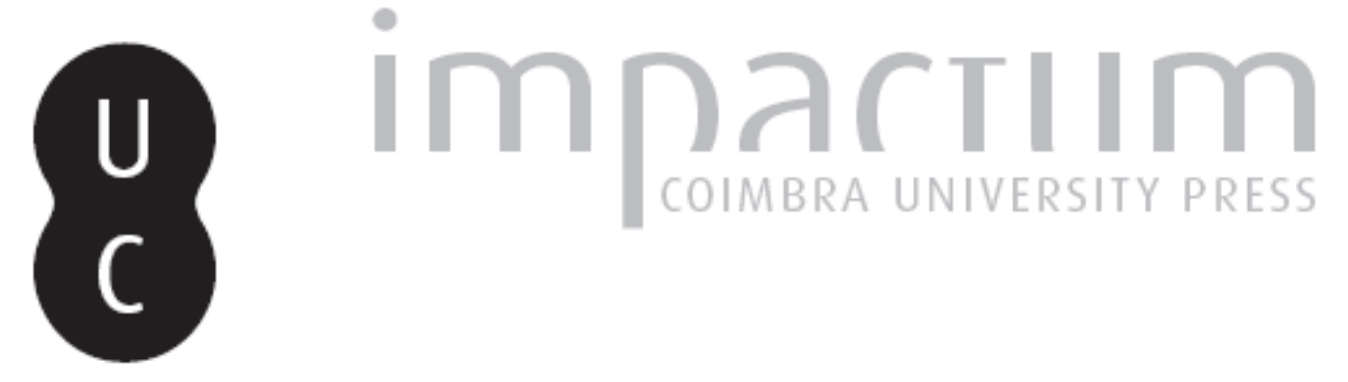

\title{
O palácio, do mundo minoico ao helénico: mito e realidade
}

Autor(es): $\quad$ Pereira, Maria Helena da Rocha

Publicado por: Imprensa da Universidade de Coimbra

URL persistente:

URI:http://hdl.handle.net/10316.2/45476

DOI:

DOI:https://dx.doi.org/10.14195/1647-8657_32_33_2

Accessed : $\quad$ 26-Apr-2023 06:46:47

A navegação consulta e descarregamento dos títulos inseridos nas Bibliotecas Digitais UC Digitalis, UC Pombalina e UC Impactum, pressupõem a aceitação plena e sem reservas dos Termos e Condições de Uso destas Bibliotecas Digitais, disponíveis em https://digitalis.uc.pt/pt-pt/termos.

Conforme exposto nos referidos Termos e Condições de Uso, o descarregamento de títulos de acesso restrito requer uma licença válida de autorização devendo o utilizador aceder ao(s) documento(s) a partir de um endereço de IP da instituição detentora da supramencionada licença.

Ao utilizador é apenas permitido o descarregamento para uso pessoal, pelo que o emprego do(s) título(s) descarregado(s) para outro fim, designadamente comercial, carece de autorização do respetivo autor ou editor da obra.

Na medida em que todas as obras da UC Digitalis se encontram protegidas pelo Código do Direito de Autor e Direitos Conexos e demais legislação aplicável, toda a cópia, parcial ou total, deste documento, nos casos em que é legalmente admitida, deverá conter ou fazer-se acompanhar por este aviso.

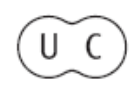




\section{UNIVERSIDADE DE COIMBRA \\ FACULDADE DE LETRAS}

\section{CONIMBRIGA}

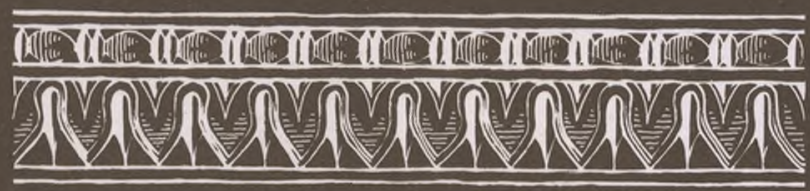

VOLUMES XXXII-XXXIII-1993/94 


\section{Maria Helena da Rocha Pereira}

Professora da Faculdade de Letras de Coimbra

\section{O PALÁCIO, DO MUNDO MINOICO AO HELÉNICO:}

\section{MITO E REALIDADE}

«Conimbriga» XXXII-XXXIII (1993-1994), p. 57-74

Resumo: As referências dispersas dos Poemas Homéricos à lenda do Labirinto

de Creta e, sobretudo, a esperança de decifrar algumas tabuinhas numa escrita desconhecida levou, como se sabe, Sir Arthur Evans a fazer escavações sistemáticas em Cnossos. Contudo, tardou cerca de meio século a decifrar o Linear $\mathrm{B}$ e mais uns anos a identificar alguns nomes que pareciam relacionados com o velho mito. À medida que avançou o conhecimento de monumentos hititas e egípcios, surgiu a questão da possível relação dessa espécie de edifícios com modelos orientais, relação que tem sido posta em dúvida pelos maiores especialistas. Por outro lado, a teoria de Evans, de que Cnossos era um palácio real e centro administrativo, foi recentemente impugnada por Castleden, que supõe que era um templo administrado pelas sacerdotisas retratadas nos frescos. A autora discute estas teses novas e apresenta argumentos em contrário. Refere também as semelhanças entre os palácios micéni$\cos \mathrm{e}$ as descrições de megara em Homero, que têm levado a uma infindável discussão. Refere ainda algumas ruínas do séc. VI a. C., bem como o palácio representado no Vaso François. Os dados relativos ao período arcaico tardio e à época clássica constam de pinturas de vasos que ilustram cenas dramáticas e de diversas referências literárias dispersas em Pindaro e nos trágicos. Quanto aos palácios helenísticos, são agora mais bem conhecidos, especialmente depois das espectaculares escavações em Vergina. As de Pérgamo, se confrontadas com a descrição de Alexandria por Estrabão, mostram que, nessa época, os palácios se tinham tornado um símbolo de prestígio e de poder.

Sumary: The scanty references of the Homeric Poems to the legend of the labyrinth of Crete and, most of all, the hope of deciphering an unknown 
writing led, as is well known, Sir Arthur Evans to excavate Cnossos in a systematic manner. Nevertheless, it took nearly half a century to decipher Linear B and still a few years more to identify some names apparently connected with the old myth. As knowledge of Hittite and Egyptian monuments progressed, the question arose whether that kind of building was related to Eastern patterns. This has been doubted by many leading scholars. On the other hand, Evans's contention that Cnossos was a royal palace and an administrative center has recently been challenged by Castleden, who thinks it was a temple under the administration of the priestesses portrayed on the frescoes. The present writer discusses these new theses and advances some arguments against them. She also refers to similarities between the Mycenaean palaces and the descriptions of the me gara in Homer, a subject which has led to a never ending discussion. A few ruins of the sixth century B. C. together with the palace represented in the François Vase are also mentioned. Vase-paintings showing dramatic scenes and several scattered literary references in Pindar and the tragics summarize the evidence concerning the Late Archaic and the Classical Ages. As to palaces in Hellenistic times, they have now become better known, specially after the spectacular excavations at Vergina. Excavations at Pergamon, when confronted with Strabo's description of Alexandria, show that by then palaces had become a symbol of prestige and power. 


\section{O PALÁCIO, DO MUNDO MINOICO AO HELÉNICO: MITO E REALIDADE}

São bem conhecidas as figuras principais que lendas muito antigas ligavam à ilha de Creta: Minos, o rei, filho de Zeus e de Europa, raptada pelo deus supremo sob a forma de touro; sua mulher Pasífae; o Minotauro, fruto da união monstruosa desta última com um touro; Dédalo, o construtor prodigioso do Labirinto onde aquele ser teratologico estava encerrado; Teseu, um dos jovens atenienses mandados como tributo ao rei, que, graças ao novelo de fio que lhe deu Ariadna, a filha do monarca, consegue reencontrar a saída da confusa edificação, arrebata a princesa, mas depois a abandona na ilha de Naxos, onde Diónisos a vem buscar para esposa, pelo que, em castigo da sua ingratidão, se esquece de içar a vela branca que anunciaria de longe a seu pai, o rei de Atenas, a vitória, e este se atira, desesperado, ao mar. Outras figuras ainda estão ligadas a estas histórias, que conhecem variantes numerosas. Algumas dizem respeito à capacidade de inventiva de Dédalo, que, após tantos anos de exílio em Creta, ansiava por regressar com seu filho ícaro, e constrói para esse efeito asas com penas de diferente tamanho, ligando-as com linho no meio e cera em baixo. Todos sabem a conclusão da história: ícaro aproxima-se demasiado do Sol, não obstante os conselhos do pai, pelo que a cera se funde e ele cai ao mar que dele tomará o nome. Um exemplo característico da mitologia grega, pois combina uma história de insolência (hybris) com um aition que explica a origem de um nome geográfico; e, lá no fundo, a ânsia humana de auto-superação.

Mas voltemos a Creta. Homero já fala do local e de algumas destas figuras, numa das mais belas cenas da descrição do escudo de Aquiles (Ilíada XVIII. 590-598): 


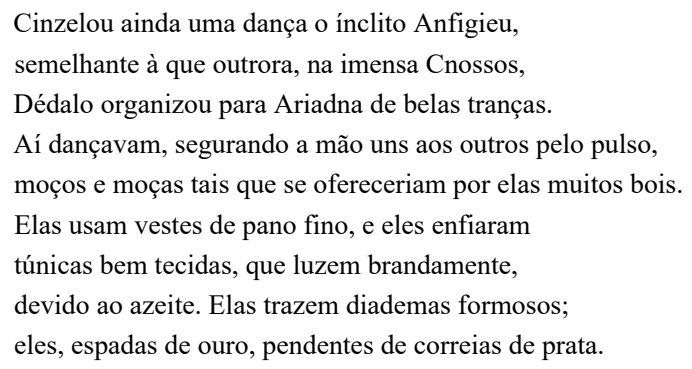

Entre os heróis da coligação aqueia que cerca Tróia, ocupa lugar de certo relevo Idomeneu, rei de Creta, que se distingue no combate pelas naus e se gloria de ser neto de Minos, descendente de Zeus (XIII. 449-454).

No decurso da Odisseia, o errante Ulisses recorre com frequência a histórias cretenses, sempre que precisa de disfarçar a sua identidade. Acaba por inventar mais uma, mesmo diante de Penèlope, quando esta o interroga sobre a sua origem: era irmão de Idomeneu e, como ele, descendente de Minos que reinara nove anos na grande cidade de Cnossos, naquela formosa e produtiva ilha de Creta que ficava no meio do pélago cor de vinho e tinha noventa cidades (XIX. 172-181). O passo é muito suspeito para os estudiosos, pois é o único onde, entre os diversos povos que se misturavam no local, se referem também os Dorios. Mas isto é outra história, da qual temos de nos afastar, sob pena de cairmos em plena Questão Homérica. Fixemos apenas o número convencionalmente elevado das cidades cretenses e a fertilidade da região.

Deste passado glorioso não tinha ficado mais que a memória dos mitos. Localizado o sítio de Cnossos por alguns no séc. XIX, só a partir de 1900 é que aí começam as escavações sistemáticas de Sir Arthur Evans, que vão pondo a descoberto os diversos compartimentos (cerca de 300) de uma enorme edificação (perto de $20.000 \mathrm{~m}^{2}$ de área), que ele reconhece ser anterior aos palácios micénicos, já então reencontrados por Schliemann e Dõrpfeld, e que identifica como o palácio do rei Minos. Era uma civilização mais antiga, a que naturalmente o grande arqueólogo deu o nome de minoica, que ainda hoje se conserva. Uma planta complexa, com um sem-número de divisões em volta de um extenso pátio central rectangular (fig. 1), uma sala com um trono, pórticos sustentados por colunas de madeira a afunilar para a base de gesso (que sugerem o primitivo uso de troncos de árvore invertidos, para não tomarem a ganhar 
raízes), uma altura de dois ou três pisos, ligados por uma escadaria de largos degraus, iluminação pelos chamados "poços de luz", um sistema de esgotos surpreendente, e, sobretudo, frescos, muitos frescos, com desenhos finos e cores contrastantes, com predomínio do azul e vermelho, e gemas trabalhadas, num conjunto que ajudava a reconstituir a forma do edifício e a vida dos seus habitantes. Dois motivos repetidos por toda a parte, certamente de valor emblemático: a bipene ou machado de dois gumes e os chamados "chifres da consagração".

Seria esse o palácio de Minos, com uma vasta área de aposentos do rei e, do outro lado, os da rainha, com uma sala do trono de modestas dimensões ( $6 \times 4 \mathrm{~m})$, com armazéns para guardar os tributos, talhas enormes para os receber, tudo em ligação com as funções produtivas e distributivas do local; e ainda tabuinhas com inscrições que não se conseguiam 1er - precisamente a razão primeira do empreendimento de Sir Arthur Evans.

Levou quase meio século (1953) a decifração de um dos silabários utilizados nessas placas de argila, aquele a que se convencionou chamar Linear B. É a partir de então que começam a surgir numerosas confirmações das hipóteses propostas. Assim, à surpresa de a língua assim grafada ser já uma forma muito antiga do grego, vem somar-se a da menção do nome daquele local - ko-no-so (Knossos) - e de outros com construções de planta semelhante, embora de proporções mais modestas, que entretanto foram sendo escavados na ilha de Creta $a-m i$-ni-so (Amnisos), pa-i-to (Phaistos) -, bem como a do Labyrinthos (da-pu-ri-to-jo), do Daidaleion e de Teseu. Ora Labyrinthos tem manifestamente na sua composição o sufixo (que em geral se tem por minóico) - nth - (o mesmo que figura no nome de Radamanto, irmão de Minos) e, segundo Kretschmer ('), derivaria de labrys, a palavra a que Plutarco ( Moralia302 a) atribuía origem lidia e que significava “machado de dois gumes' ou 'bipene', isto é, precisamente um dos símbolos mais repetidos em Cnossos. Esta etimologia não tem, no entanto, aceitação geral, e o autor do mais recente dicionário etimológico grego (Chantraine, 1980), não toma posição.

Sucede ainda que o contexto em que aparecem as palavras po-ti-

(') "Die vorgriechischen Sprach- und Volksschichten", dotta 28 (1939) 231-279. Sobre as dúvidas quanto à origem egeia do sufixo, vide W. Burkert, The Orientalizing Revolution. Near Eastern Influence in Early Archaic Age (Harvard University Press 1992) 176, nota 24. 
ni-ja da-pu-ri-to-jo sugere o significado de "A Senhora do Labirinto", a qual poderia ser uma das principais divindades minóicas há tanto tempo procuradas. Porém, como adverte aquele que é actualmente considerado o melhor especialista da religião grega, o Prof. Walter Burkert, nem com respeito a essa designação, nem quanto ao Daidaleion as tabuinhas dão indícios do seu significado exacto. Por outro lado, observa ainda, tanto a bipene como os chifres da consagração parecem ligar-se a uma tradição anatólia( $\left.{ }^{2}\right)$. Recordemos a este propósito que o grande templo de Hattusa, capital do império hitita sediado na Ásia Menor, possuía também uma planta muito complexa e assimétrica; e que sabemos por Herodoto (II. 148), Diodoro Siculo (66.1-6), Estrabão (XVII. 1.37), Plínio (XXXVI. 13), e Pomponio Mela (I. 9) que se passava algo de semelhante com aquilo que os gregos chamavam o Labirinto do Egipto, o de Hawara.

Templo ou monumento funerário, como o segundo, - em qualquer destas aplicações, estamos longe da de Evans, que sempre defendeu a tese de que Cnossos era um palácio real e centro administrativo, posição essa que tem continuado a ser sustentada pelos melhores especialistas, como Sinclair Hood e Nicolas Platon (o arqueólogo que descobriu o palácio de Zakros). Por outro lado, as opiniões dos diversos historiadores reunidos num congresso sobre o sistema palacial antigo, realizado em Estrasburgo em 1985, inclinam-se para ver urna total independência da arquitectura de Creta em relação a modelos orientais (3).

Mas outras hipóteses têm vindo a ser propostas ultimamente, de que destacaremos duas, a de Wunderlich (The Secret of Crete, 1975), que defende que aquela construção colossal não era mais do que um palácio dos mortos, semelhante ao de Hawara, há pouco citado, e a de Castleden (The Knossos Labyrinth. A new view of the Palace of Minos at Knossos, 1990), segundo a qual estaríamos perante um grandioso templo, onde se prestava culto aos numerosos deuses da religião minoica, onde eram recebidas as múltiplas dádivas de que se conservaram vestígios, e onde a autoridade suprema era, não um rei, mas as

(2) Griechische Religion der archaischen und klassischen Epoche (Stuttgart 1977) $54-55,73-75$.

${ }^{3}$ ) Especialmente o artigo de O. Pelón, "Particularités et développement des palais minoens". Agradeço a possibilidade de consulta das Actas, editadas por E. Lévy em 1987 com o título Le Système Palatial en Orient, en Grèce et à Rome (daqui em diante citado só como Le Système Palatial) ao Doutor José d'Encarnação. 
sacerdotisas a que os frescos atribuem um lugar proeminente.

Concentrando-nos apenas nesta segunda tese, notaremos que um dos seus pontos de apoio reside precisamente nos frescos e na escassez de representações do rei. Segundo Castleden, o célebre "Príncipe das Flores de Lis", única figura que poderia ter esse significado, teria sido arbitrariamente reconstituída por Evans quanto a um dos seus atributos identificativos - a espécie de tiara que ostenta na cabeça (fig. 2). Esse adereço pertenceria a um animal fantástico, um grifo que aquela figura masculina conduzia no cortejo. Deste modo, os atributos do "Príncipe" deslocavam-se para o animal, perdendo aquele toda a sua preeminência (fig. 3). Julgamos, porém, que a comparação com um fresco que apareceu em Micenas (fig. 4), que representa uma figura feminina com idêntico toucado, demonstra suficientemente que se tratava de um atributo da realeza $\left(^{4}\right)$.

A pluralidade de deusas supostas por este autor, para além das já consagradas "Senhora dos Animais Selvagens" e "Senhora do Palácio", e a atribuição de compartimentos especiais para o culto de cada uma vem contrariar a tese tradicional, retomada em anos recentes por Graham (1987) e Rutkowski (1986), segundo a qual os Minóicos não tinham templos. Para Castleden, a sua própria interpretação viria colocar os cretenses num contexto cultural semelhante aos dos egípcios e dos hititas, pois, desde que identifiquemos os palácios como templos, "rectificamos uma anomalia cultural das maiores" (p. 165). Por conseguinte, o palácio real seria, quando muito, a chamada "Mansão Inexplorada" (Unexplored Mansion), escavada de 1968 a 1973, e com uma sala do trono não muito menor do que a dos reis de Pilos $(10 \times 8$, ao passo que a de Cnossos mede $6 \times 4$, conforme já dissemos); ou então, estaria ainda por encontrar.

Um templo de enormes dimensões, que atingiria cerca de mil divisões, contando com as dos andares superiores, construído em volta de um grande pátio central onde teria lugar o famoso "Salto do Touro" (ao invés do que conjecturou Evans, com base no excessivo número de entradas e saídas desse recinto) é, portanto, o que Castleden pretende ver em Cnossos. A tese, aliás não inteiramente nova, parece pouco provável, uma vez que se apoia quase só em conjecturas derivadas da ausência de dados seguros. Recorde-se o caso da escultura cretense, sobre a qual se repetiu durante anos consecutivos que se limitava ao

$\left({ }^{4}\right)$ Como tal o interpreta E. Karkopodini-Dimitriadi, Der Peloponnes. Ein Reiseführer zu den historischen Stätten, Monumenten und Museen (Athen 1990) 86-87.

Conimbriga, 32-33 (1993-1994), 57-74 
trabalho miniatural, pois não se conheciam exemplos noutras dimensões, até que o achado de numerosas estátuas femininas do séc. XV a. C. em Ceos veio pôr de parte definitivamente esta restrição tirada de um argumentum ex silentio. Pelo que toca à religião minoica e à finalidade do palácio de Cnossos, é de crer que só a decifração do Linear A poderá esclarecer o assunto. Até lá, tudo permanecerá o "álbum sem legendas" de que falou Nilsson. Recorde-se além disso que vários outros palácios, como Phaistos, Mallia, Zakros, apresentam uma configuração semelhante ao de Cnossos, embora em cada um deles o pátio central não esteja tão próximo do centro geométrico. Por outro lado, a grandiosidade deste supera em muito a dos outros, facto que tem levado a pensar que exerceria uma certa supremacia sobre os restantes.

E hoje ponto assente para a maioria dos especialistas que durante o período geralmente designado por Minoico Recente, os Micénios são senhores de Cnossos. E este, de resto, o único palácio cretense que continua a ser habitado depois da grande erupção de Tera, cerca de 1470 a. C., que abalara toda a área em redor, tal como havia de suceder modernamente com a do Krakatoa, em 1883.

Se esse domínio compreende cerca de um século, aliás extremamente brilhante (1470-1380 a. C), ou se se estende até ao séc. XII a. C., é questão muito discutida. O certo é que no continente grego, é durante o séc. XIII a.C. que os palácios micénicos estão no auge do poder. Micenas, Tirinto, Pilos, são actualmente os lugares onde se fizeram escavações mais completas que apontam todas para os mesmos princípios gerais de construção do palácio real: muralhas ciclópicas a defendê-lo, planta claramente ordenada em volta de um aposento central, o mégaron, dotado de uma ante-câmara com uma entrada única e uma lareira ao centro, flanqueada por quatro colunas (fig. 5). A decoração pictórica conserva o estilo da dos minóicos, mas acrescenta aos pacíficos jardins e cenas de corte ou de culto episódios guerreiros que, tal como a construção dos edifícios, sugere o carácter belicoso deste povo.

Quanto à relação entre os palácios, Micenas e Tirinto, além de geograficamente muito próximos, e certamente obra do mesmo construtor, como demonstrou Mylonas, embora o segundo seja esteticamente mais elaborado do que o primeiro, admite-se que fosse subordinado hierarquicamente a este último $\left(^{5}\right)$. Pilos, por seu turno, é de

$\left(^{5}\right)$ Vide Hans Lauter, "Nouveaux Aspects du Palais de Mycènes au HR IIIB" in: Le Système Palatial, 219-225.

Conimbriga, 32-33 (1993-1994), 57-74 
longe o que tem oferecido mais rica documentação.

Mas, neste ponto, às provas arqueológicas vêm somar-se as literárias, não sem conflito, todavia. É que, de palácios reais cujo aposento central é o mégaron, local onde se passa a maior parte do tempo, e com as características há pouco descritas, falam também os Poemas Homéricos, sobretudo a Odisseia, como neste passo do Canto VII (84-90):

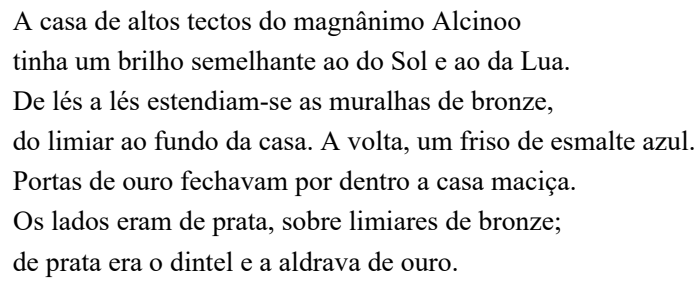

Poder-se-á objectar que o palácio do rei dos Feaces pertence às terras de sonho dos errores de Ulisses. Efectivamente, a descrição prossegue dizendo que cães de ouro e prata guardavam a entrada e "jovens de ouro, sobre pedras bem talhadas, de pé, seguravam nas mãos tochas a arder, para iluminar de noite os convivas da casa". Mas, por outro lado, um friso de esmalte azul, como o referido no texto, apareceu já no requintado palácio de Tirinto.

Temos, de resto, os paços de Menelau em Esparta, que são descritos como sendo de uma riqueza sem par pelo próprio Telémaco (IV. 71-75):

Repara, Nestórida, a quem tanto quero, no brilho do bronze, do ouro e do âmbar, da prata e do marfim, que há neste palácio rumoroso.

A corte de Zeus Olímpico é com certeza assim, de uma beleza acima das palavras; a sua vista enche-me de admiração.

Ouro, prata, bronze, marfim, de todos esses materiais se encontraram numerosos objectos nos palácios escavados. Do metal mais nobre se descobriu tal quantidade em Micenas (14 kg, mais do que em todas as restantes estações arqueológicas gregas somadas $\left(^{6}\right)$ ), que bem se justifica o epíteto que a cidade tem em Homero: "Micenas rica em

(6) Dados colhidos em G. E. Mylonas, Mykene. Ein Führer zu seinen Ruinen und seiner Geschichte (Athen 1981) 29, 92-93. 
ouro". Mas também nos túmulos se encontrou muito âmbar, a resina preciosa que o texto menciona, e que se julga indiciar a origem nórdica dos Micénios.

Voltando à terra dos Feaces, oiçamos a jovem Nausicaa descrever os hábitos dos pais (VI. 303-309):

\footnotetext{
Assim que estiveres oculto no pátio do palácio,

atravessa depressa o mégaron, para encontrares minha mãe.

Estará sentada à lareira, à claridade do lume,

fiando em sua roca cor de púrpura marinha - maravilha

de se ver - encostada a uma coluna. As servas sentam-se atrás.

Aí fica também o trono de meu pai, voltado para o clarão.

Aí sentado é que ele bebe o seu vinho, como se fora um imortal.
}

Era também no mégaron do palácio de Ulisses em Itaca que se banqueteavam diariamente os pretendentes. Será aí que o herói exercerá a sua vingança, depois de fechadas as portas da única entrada. Também aí se realizara a prova do arco, para a qual era necessário dispor no chão doze machados em fila, o que tem levado a supor que o solo era de terra batida (Canto XXI). Nessa ocasião é referido ainda o lugar de depósito das armas (XXII. 139-141), bem como o pátio onde Ulisses se assegurara discretamente da lealdade de dois dos seus servidores (XX. 162-165). O palácio tem pelo menos um andar superior, onde fica o quarto de Penèlope, pois é daí que ela escuta o aedo que canta o regresso dos heróis de Tróia e "desce a alta escadaria do seu palácio" (I. 330); é também a esse lugar que sobe a velha ama de Ulisses, quase no final do poema, para lhe dar a boa nova do regresso e da vingança do senhor da casa (XXIII. 1-3; cf. XXII. 20).

Porém a descrição mais completa do aspecto exterior da habitação é a que é ironicamente posta na boca de Ulisses, quando ele se aproxima incógnito da sua própria morada, em companhia do porqueiro Eumeu, e finge admirar a riqueza que avista (XVII. 264-268):

\footnotetext{
Eumeu, é com certeza esta a bela morada de Ulisses, e fácil seria reconhecê-la, ainda que se visse entre muitas.

De uma construção sai outra, tem um pátio bem executado, com muros e cornijas, portas de dois batentes bem defendidas. Não há homem que possa forçá-las!
}

Muitos mais pormenores poderiam mencionar-se. Mas os que 
ficam referidos chegam para nos conduzir outra vez ao âmago da Questão Homérica, pois, se há assunto, dentro desse âmbito, que tenha estado novamente em foco nos últimos anos, é o da presença ou não de elementos micénicos nos Poemas. Em breves palavras, poderá dizer-se que as opiniões se dividem entre os dois extremos de considerar micènica toda a arquitectura dos palácios e certos objectos minuciosamente descritos, como o elmo de presas de javali, a taça de Nestor, a espada de Heitor, a técnica de incrustações (Kirk) e o de afirmar que todos os motivos arquitectónicos se encontram em construções de cerca de 800 a. C. (Drerup), ou mesmo que os traços gerais são da Idade do Ferro, salvo certos pormenores, como a existência de corredores e canalizações $\left(0^{\prime} \mathrm{Knox}\right)\left({ }^{7}\right)$. O enigma resulta do desconhecimento do período chamado "Idade das Trevas", que decorre entre o colapso da civilização micènica, cerca de 1100 a. C, e a época provável de composição dos Poemas Homéricos. Achados recentes, como os do heroon de Lefkandi, na ilha de Eubeia, datáveis do séc. X a. C., testemunham a possibilidade de concentração de riqueza e prosperidade numa época que se supunha desprovida de tudo. Por outro lado, se Micenas deixou de ser "rica em ouro" na época do ferro, aquele epíteto prova que a memória do seu fausto só poderia ter sido preservada através da transmissão oral contínua de cantos épicos, numa altura em que não só a prática, mas até a lembrança do uso da escrita se perdera.

$\mathrm{O}$ mais curioso, todavia, é que, se há dúvidas quanto às recuadas épocas de que acabamos de falar, muitas mais há ainda em relação às que se lhes seguem. Do séc. VI a. C. conhecem-se apenas exemplos isolados. Um é o de um palácio da Tessália, que poderá ser o de Larissa, que foi sendo alterado ao longo de uns duzentos anos. A planta inicial comportava um aposento rectangular de $10 \times 10 \mathrm{~m}$ e um pórtico a norte com colunas in antis encimadas talvez por capitéis eólicos, embora alguns arqueólogos datem estes últimos da segunda construção, efectuada em meados do século. O palácio teria sido alargado mais duas vezes, com intervalos de meio século: numa, teria recebido um pórtico com colunas in antis, um grande salão rectangular e mais dois quartos com a mesma configuração; na outra, um pátio exterior e vários outros arranjos. Por último, acrescentou-se-lhe um aposento de pequenas

(7) G. S. Kirk, The Iliad: A Commentary. Vol. I: Books 1-4 (Cambridge 1985) 8-9; H. Drerup, Griechische Baukunst in geometrischer Zeit (Göttingen 1969); Mary O’Knox, "Megarons and Megra", Classical Quarterly 23 (1973) 1-21. 
dimensões, para fins sanitários.

Mais importante do que este, mas de menor interesse, porque planeado inicialmente de acordo com as normas da arquitectura síria, é o de Vouni, em Chipre, de cerca de 500 a. C., que, na segunda metade do séc. V sofre modificações por influência grega, uma das quais resulta da deslocação da entrada para o que eram anteriormente as traseiras do palácio, e outra a introdução de banhos quentes $\left(^{8}\right)$.

A pintura de vasos contribui também com um exemplo famoso: o do krater François, de cerca de 570 a. C., que no terceiro registo mostra um palácio com quatro colunas, encimado por um friso com triglifos e um frontão. À frente do edifício, está Peleu, pronto a receber o cortejo dos deuses que vem assistir aos seus esponsais com Tétis.

Para além disto, podemos supor que o regime político da tirania, que se generaliza na época arcaica, pressupõe também a existência de palácios opulentos, de que ficaram ecos nas odes de Pindaro como, por exemplo, na I. ${ }^{a}$ Olímpica, quanto ao de Hierão de Siracusa.

De um modo geral, a existência ou construção de palácios está ligada a um regime político bem definido, a monarquia, que vai desaparecendo na maior parte das cidades-estados do continente e das ilhas. Houve, no entanto, como todos sabem, uma excepção - Esparta -, que manteve sempre o seu sistema de monarquia dualista. Mas dessa quase nada resta. Dela pode concluir-se que foram proféticas as palavras de Tucídides (I. 10.2):

De facto, se a cidade dos Lacedemónios fosse devastada, e
ficassem apenas os templos e os alicerces das construções, creio
bem que, ao fim de bastante tempo, se suscitariam muitas descon-
fianças entre os vindouros quanto à sua glória; e, contudo, eles
governam dois quintos do Peloponeso e têm a hegemonia sobre a
sua totalidade e ainda, fora dele, sobre muitos aliados. No entanto,
como a cidade deles não é um centro único e não possui templos
nem construções opulentas, antes se distribui a sua população por
aldeias, à maneira antiga da Grécia, pareceria muito insignificante.

Quer isto dizer que teremos de prescindir por completo da época

$\left.{ }^{8}\right)$ Para mais pormenores, veja-se o tratado de A. W. Lawrence, Greek Architecture (revised with additions by R. A. Tomlinson) (Harmondsworth, repr. 1987) 315-316 .

Conimbriga, 32-33 (1993-1994), 57-74 
clássica? Não totalmente. Os palácios continuam a estar presentes, pelo menos, no imaginário dos gregos, e fizeram-no de duas maneiras: no teatro e na pintura de vasos. É a esses dados que vamos agora recorrer.

Uma parte considerável das tragédias gregas conservadas tem por cenário a frontaria de um palácio, embora esta raramente seja descrita. Duvida-se mesmo se existem ou não três portas praticáveis. Mas, por exemplo, as Coéforas de Ésquilo supõem uma entrada para o gineceu (v. 878) e uma para os quartos dos hóspedes (vv. 712-713). Este último tipo de aposentos é igualmente referido e desempenha papel importante na Alceste de Eurípides (vv. 543-546). A presença de altares na frente do palácio é repetidamente assinalada no Agamémnon de Esquilo, no Rei Édipo e Electra de Sófocles, no Hipólito de Eurípides. A existência de um terraço está documentada no já referido Agamémnon, pois é daí que profere o prólogo o guarda ali postado todas as noites por Clitemnestra, durante dez anos, até receber os sinais luminosos anunciadores da tomada de Tróia. Num terraço decorre a acção do êxodo do Orestes de Eurípides, com as figuras sinistras de Orestes, Pílades e Electra a preparar-se para sacrificar a inocente Hermione, e o príncipe micènico a dar ordem de incendiar o palácio. Esta movimentada peça é justamente uma das que contêm mais elementos descritivos, quer na cena do aparecimento do escravo frigio, quer na narrativa que ele posteriormente faz do que se passara no interior. O referido escravo aparece em cena a contar que fugira da espada argiva passando "pelas traves de cedro dos pórticos e pelos triglifos dóricos” (vv. 1369-1372), o que pressupõe a existência de aberturas nos triglifos que não sabemos explicar (a situação repete-se em Ifigénia entre os Tauros, v. 113, mas

$\left(^{9}\right)$ O texto oferece outras dificuldades ainda, pois nos versos 1366-1368 o coro anunciara estar a ouvir o ruído das chaves da porta do palácio, o que queria dizer que algum dos frigios conseguira evadir-se, e logo a seguir o escravo entra em cena da maneira referida no texto supra. O escoliasta antigo apercebeu-se da incoerência e logo anota que os três versos anteriores resultavam de uma interpolação feita por actores que receavam magoar-se ao dar um salto desses em cena. Por isso, os mais autorizados editores modernos (W. Biehl, 1975; J. Diggle, 1994) continuam a dar o passo como suspeito. A. W. Pickard-Cambridge, The Theatre of Dionysus in Athens (Oxford 1946) 53-55, supõe que o frigio aparece a primeira vez sobre um paraskenion e dai salta para o chão, a fím de falar com Orestes (v. 1507). Para outras soluções ainda menos convincentes, vide o comentário de M. L. West à sua edição (Warminster 1987) 275-276; os principais argumentos a favor e contra, bem como a respectiva bibliografia, podem ver-se no comentário de C. W. Willink (Oxford 1986) 305-306. 
aqui é relativa a um templo) ${ }^{9}$ ). Repare-se na riqueza representada pela madeira de cedro, material de que também é feita a escada pela qual Antigona sobe ao terraço do palácio, pela mão do pedagogo, na segunda parte do prólogo de As Fenícias de Eurípides, para ver os sitiantes de Tebas.

A narrativa do escravo frigio em Orestes, de que estávamos a tratar, refere-se ao aposento onde Helena se encontrava a fiar, enquanto ele abanava em sua frente um leque de plumas, e alude ainda aos muitos compartimentos - diversas salas, e ainda exedras e estábulos em que Orestes e Pílades fecham à chave os servidores que faziam séquito à rainha de Esparta.

Da existência de estábulos ao lado do palácio e a ele pertencentes falam também As Bacantes do mesmo autor, mas não se limitam a essa indicação. Há um momento, cuja representação cénica é objecto de larga discussão, em que o Coro vê - ou julga ver - a arquitrave de pedra deslocar-se sobre as colunas (vv. 591-593). Depois, no êxodo, quando Agave regressa delirante com a cabeça do filho, julgando tratar-se de um leão, pretende que Penteu mande trazer uma escada para a encostar ao muro, subir os degraus e cravar nos triglifos a cabeça da suposta fera, como um troféu magnífico, por ela caçado (vv. 1211-1215). Estes passos, que pertencem ao horripilante clímax da tragédia, servem para demonstrar que a construção de um palácio real é mais ou menos visionada como a de um templo e possui aproximadamente os mesmos elementos decorativos.

É o que sucede também com outra tragédia de Eurípides, Héraclès, na descrição dos actos de loucura a que é levado o grande herói. Fala-se da grande sala dos banquetes (dcvôpóv, v.954), das colunas a cuja sombra se refugia um dos filhos, correndo depois ern sua volta (vv. 973-974, 976-982), e daquela a que Héraclès, finalmente adormecido por Atena, é amarrado (vv. 1003-1011). Se as colunas mencionadas em primeiro lugar faziam parte do prothyron ou pórtico, como julgam muitos especialistas, é duvidoso, pois é mais provável que, conforme defendeu A. W. Pickard-Cambridge, a expressão tão usada de npóOupoc ôcopiáTwv signifique apenas a entrada do palácio $\left({ }^{10}\right)$.

Esta semelhança geral é confirmada pelas pinturas de vasos que ilustram peças de teatro, embora talvez só uma delas, um fragmento de

(10) Op. cit., 75-76. 
um calyx-krater de Tarento, em Würzburg (fig. 6) represente um cenário tal como ele era pintado depois de Agatarco. Os restantes servem, porém, para imaginar como os artistas viam um palácio: um pórtico com frontão e duas ou mais colunas deixa ver um número variável de figuras no seu interior, e outras fora dele, em diversos níveis. Essas cenas de interior correspondem frequentemente às partes narradas, pois são cenas de violência. Dois exemplos apenas de muitos que poderiam apresentar-se: o \&rater-de-volutas de Canossa, em Munique (fig. 7) com a vingança de Medeia (na edícula está representada a morte de Creusa e do pai, devido aos venenos da feiticeira, mas no conjunto, não é exactamente a versão dada na peça homónima de Eurípides); a situla em Villa Giulia com Pélops e Enómao (fig. 8), onde as cabeças dos cavalos, alusivas à futura competição entre os dois, provam, como observou Pickard-Cambridge, não poder tratar-se de um cenário, ainda que a história ilustrada possa ser a que serviu de base ao Enómao de Sófocles ou ao de Eurípides (u).

Muitos destes vasos são de pintores da Itália do Sul, o que, ao contrário do que se tem afirmado, não diminui o seu valor informativo: por um lado, porque os primeiros mestres dos estilos que se desenvolveram na Magna Grécia eram de origem ateniense; e por outro, porque a recepção do teatro grego nessa região tinha atrás de si uma longa tradição (recordem-se histórias como a da libertação de prisioneiros atenienses, após a derrota da Sicília por saberem recitar tiradas de Eurípides). E também não foi por acaso que Esquilo morreu nessa mesma ilha, em Gela, ele que mais do que uma vez foi convidado de Hierão de Siracusa.

Passando à época helenística, os dados começam a ser mais numerosos, e o aparato das residências em extensão e decoração cresce com o advento das novas monarquias. O exemplo mais notável vem das espectaculares escavações de Vergina, que compreendem, para além dos túmulos reais (incluindo o que é certamente o de Filipe II), o edifício que tudo indica tenha sido o palácio dos novos reis da Macedonia, os Antigónidas (fig. 9). Dotado de um grande pátio central, com dezasseis colunas de cada lado e uma larga entrada de porta tripla ao centro da fachada oriental, dispunha de múltiplos aposentos, dos quais vários parecem ter sido salas de banquetes solenes. Entre estes distinguem-se,

(n) Op. cit., 94 . 
pela sua riqueza decorativa, os do lado Sul que ostentam nas portas limiares de mármore maciço e, no chão, belos painéis de mosaicos. Do lado ocidental ficam três grandes aposentos que, pelas suas dimensões, pressupõem uma nova técnica de execução da respectiva cobertura, e podiam acomodar um maior número de leitos para os convivas. Do lado oposto, um pequeno quarto de planta circular, adjacente à entrada principal, tem dado lugar às mais díspares interpretações quanto ao seu uso, quer como sala do trono, quer como casa de banho, quer como lugar para jogar o kottabos, entretenimento favorito dos gregos. A verdade é que nenhuma destas hipóteses parece ter grande viabilidade, muito menos a última, pois as pinturas de vasos mostram que tal jogo se realizava habitualmente no lugar dos banquetes. Surpreendente no meio desta opulência geral é o facto de as paredes do palácio serem construídas, das faixas de pedra para cima, com tijolos não cozidos. Finalmente, um pátio adicional a poente terá pertencido à área de serviços. O conjunto forma, portanto, uma construção de grande aparato, ligada às recepções oferecidas pelos monarcas (12).

Soberbos terão sido, pelo menos na sua colocação, os palácios reais de Pérgamo, relativamente pequenos, mas totalmente rodeados de colunas com os interiores decorados com estuques coloridos nas paredes - de que se encontraram fragmentos - e mosaicos sumptuosos no solo (fig. 10).

Se da cidade rival desta nada temos, ficou pelo menos nos livros a memória dos esplendores de Alexandria. Aquele que é talvez o mais famoso dos Idílios de Teócrito sugere-nos em poucos versos o espanto causado em duas mulheres siracusanas que habitam na grande urbe e se dirigem ao "opulento palácio real de Ptolomeu", onde entram a custo, no meio de uma grande multidão, para assistir ao canto de Adónis (XV. 78-83):

Gorgo - Praxínoa, vem por aqui. Olha primeiro para estas tapeçarias.

Que finas! Que formosas! Dir-se-ia para uso dos deuses!

Praxínoa - Atena venerável, que artistas os que as executaram!

Que pintores os que desenharam tão perfeitas figuras!

Que posições tão exactas, que movimentos tão certos!

São vivas, não são tecidas. Que esperta coisa é o homem!

(12) A maior parte destes dados é extraída do tratado de A. W. Lawrence, The Greek Architecture, citado na nota 8.

Conimbriga, 32-33 (1993-1994), 57-74 
Esta composição é do séc. Ili a. C. Cerca de duas centúrias depois, o geógrafo Estrabão deixou uma descrição das grandezas da cidade, a que não falta a alusão aos palácios reais (Geografia XVII. 1.8):

Tem esta cidade os mais belos recintos públicos e os palácios
reais, que representam um quarto ou mesmo um terço do seu cir-
cuito total. Porquanto, assim como cada um dos reis tinha um amor
pela beleza que o levava a enriquecer com qualquer adorno os
monumentos públicos, do mesmo modo erigia, a expensas próprias,
uma nova edificação em volta das já existentes, de tal forma que
actualmente, como diz o Poeta,

"de uma construção sai outra".

Todas são, contudo, interligadas, quer entre si, quer com o porto, incluindo as que ficam fora dele. Faz parte dos palácios reais o Museu, dotado de um passeio coberto e de uma exedra e de uma grande casa, na qual fica a sala de refeições dos eruditos que pertencem ao Museu.

Refere ainda a existência de um lugar onde se encontravam os túmulos reais, entre eles o de Alexandre, como parte dos palácios acabados de descrever.

A grande importância deste passo e do que se lhe segue reside na referência ao Museu e ao modo como lá viviam os investigadores dessa grande instituição científica. Mas não deixam de ser instrutivos os dados sobre a extensão dos palácios reais em relação à cidade ("um quarto ou mesmo um terço") e ao espírito competitivo que animava a sua construção e embelezamento.

Outros dos reinos desmembrados do império de Alexandre eram famosos pelo esplendor dos seus palácios. Um dos exemplos mais célebres ficou retratado no texto do historiador Polibio, que hesita em descrevê-lo, com receio de que julguem tratar-se de um exagero retórico. Trata-se do palácio de Ecbátana, outrora residência real dos Medos. Tinha cerca de sete estádios de perímetro e era construído com madeiras todas de cedro ou de cipreste, sem que nenhuma delas estivesse a descoberto, pois as traves, caixotões e colunas dos pórticos e dos passeios cobertos eram revestidas de lâminas de prata ou de ouro, e as lajes todas de prata. Tantos eram os metais preciosos que, embora Alexandre e os Macedonios levassem a maior parte e o resto desaparecesse durante o 
reinado de Antigono e Seleuco, filho de Nicanor, quando Antioco levou o que ficara no templo de Ene, deu ainda para cunhar moeda com a efígie do rei num total de quase quatrocentos talentos (Histórias X. 27. 3-13).

$\mathrm{O}$ ideal de riqueza tornara-se fonte de prestígio no mundo helenístico, e o palácio real simbolizava o seu mais alto expoente. Mas, por outro lado, há aqui a preocupação de ligar à realeza uma série de instituições que continuavam a fazer recordar as de uma antiga cidade grega. Como escreveu com grande agudeza H. Lauter, "é evidente que os santuários; o túmulo do herói ktistes ou seu equivalente, o he won da dinastia; o teatro; a ágora - no ponto em que estava próxima do palácio; e mesmo as bibliotecas derivam de uma tradição das cidades gregas livres; podiam mesmo definir-se como instituições republicanas [...] Abstraindo das moradas privadas dos príncipes, mais ou menos ricamente equipadas, os vestígios arquitectónicos de uma regia parecem-se com os que se poderiam encontrar no centro monumental de uma metrópole grega qualquer" $\left({ }^{13}\right)$. Porém à evidente preocupação de ostentação não será estranho, como aventou Claire Préaux, um certo modelo oriental (14).

Fechara-se, pois, o ciclo? Não podemos dizê-lo. Sabemos, por estarem arqueológicamente comprovadas, das relações comerciais de Creta e Micenas com o Egipto, o Próximo Oriente, a Babilónia. É arriscado falar de influências artísticas, a não ser, segundo julgamos, para o caso isolado do sarcófago de Hagia Triada. Estamos perante uma série de questões em aberto que aguardam resposta e que estão presentemente a ser estudadas (repare-se que a intenção principal do responsável pela nova campanha de escavações na Tróade, o Prof. Manfred Korfmann, é reconstituir as relações entre a Europa e a Asia na Idade do Bronze no principal ponto de contacto entre os dois continentes).

No meio dos dois extremos deste grande arco cronologico, que vai de cerca de 1900 a. C. a 146 a. C., ambos marcados, no que toca a palácios reais, pela ambição do espectacular, fica a moderação, a acocppoaóvp característica da época clássica, em que o cidadão é participante dos destinos da vida colectiva da polis, porque é ele que $\mathrm{p} £ \mathrm{~T} £ \mathrm{x}^{L}$ xpiastoç xocL ocpxTQÇ, "tem parte na decisão e no comando", como escreveu Aristóteles, com a sua precisão exemplar ( $\left.{ }^{15}\right)$.

(13) "Les Éléments de la Regia Hellénistique" in: Le Système Palatial. As citações são da p. 353.

$\left.C^{4}\right)$ Le Monde Hellénistique. La Grèce et VOrient (323-146 avant J. - C.) (Paris 1978), Tome I, 208-209.

(15) Política III, 1275 a.

Conimbriga, 32-33 (1993-1994), 57-74 


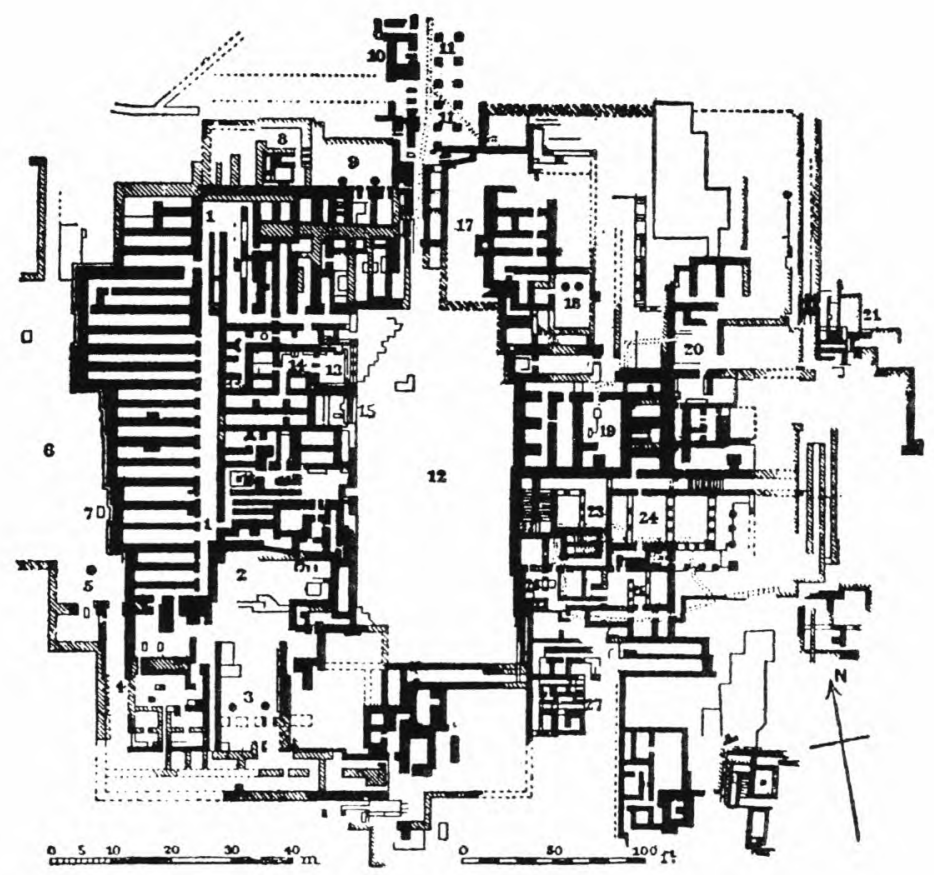

FIG. 1 - Planta do Palácio de Cnossos

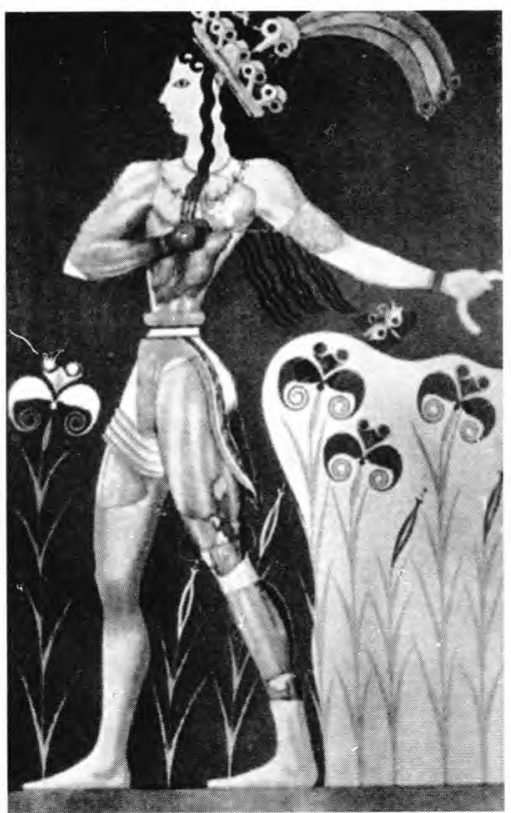

Fig. 2 - Palácio de Cnossos. O fresco do Príncipe das Flores de Lis 


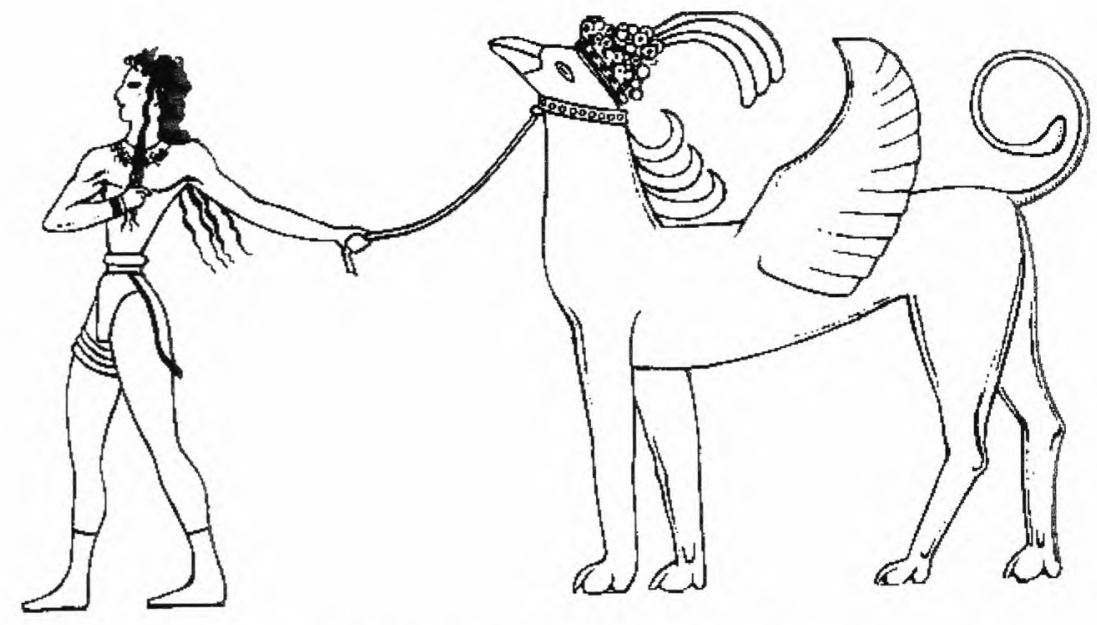

FIG. 3 - O Príncipe das Flores de Lis, na reconstituição de Castleden

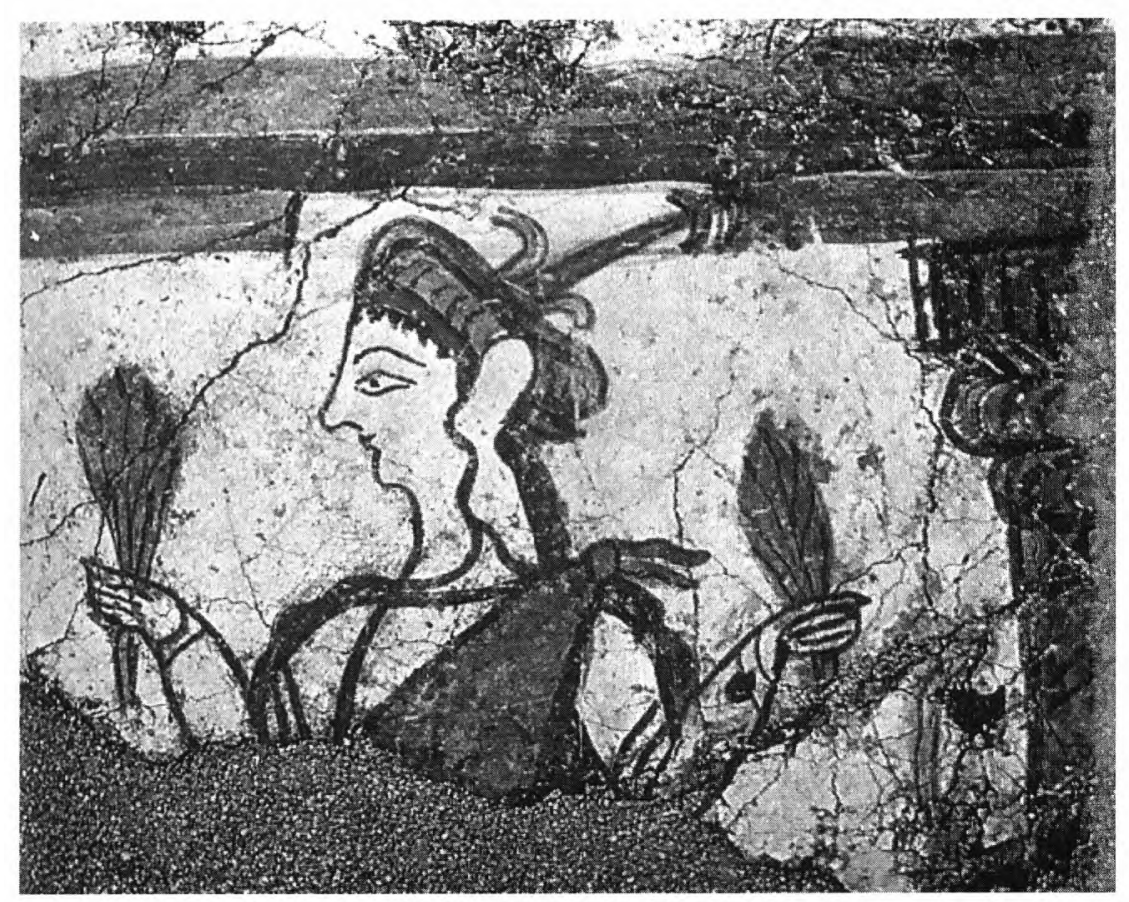

FIG. 4 - Micenas. Fresco com uma figura feminina 


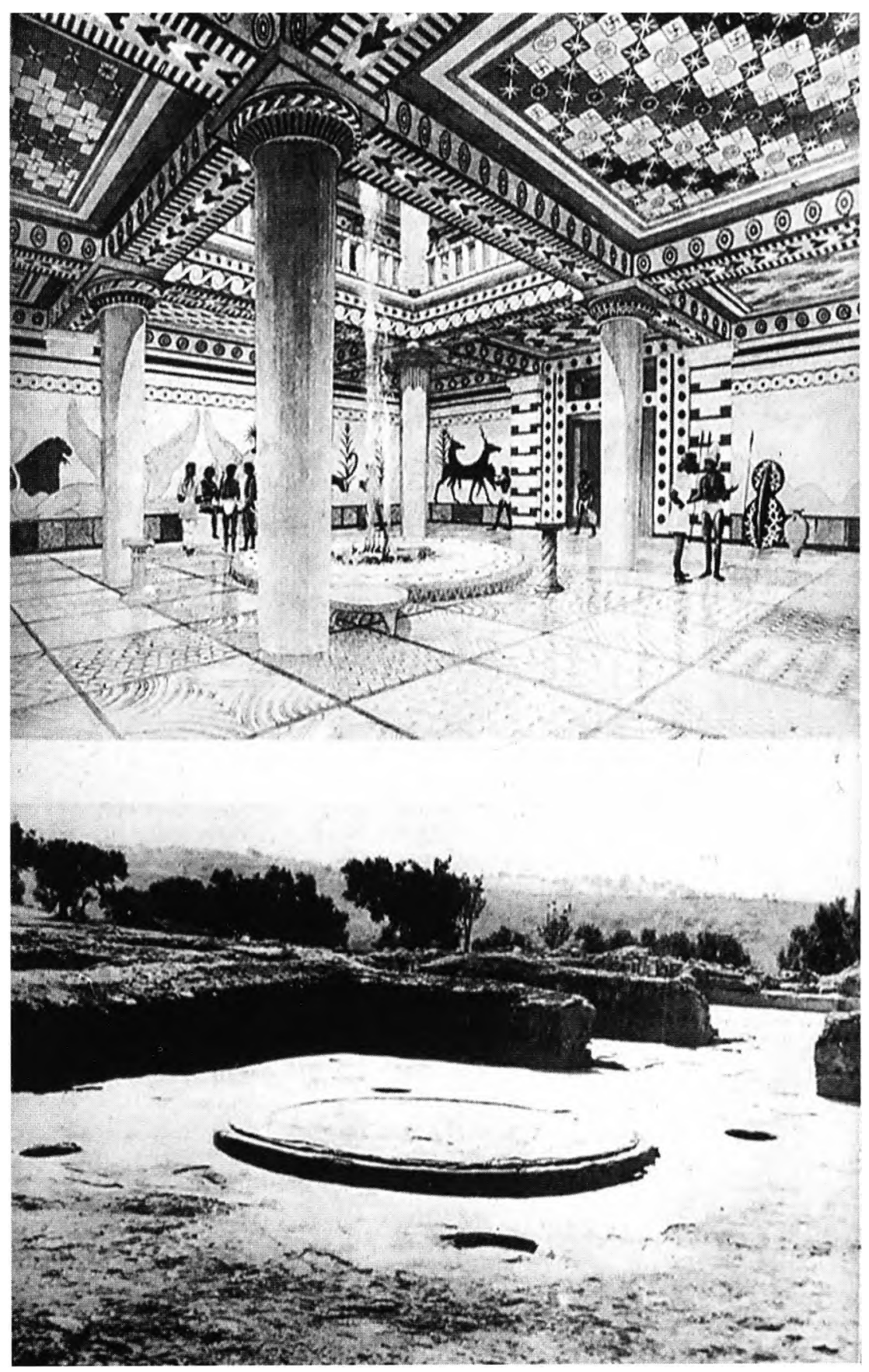

FIG. 5 - Pilos. Palácio real. Em baixo, o mégaron; em cima, uma reconstituição 


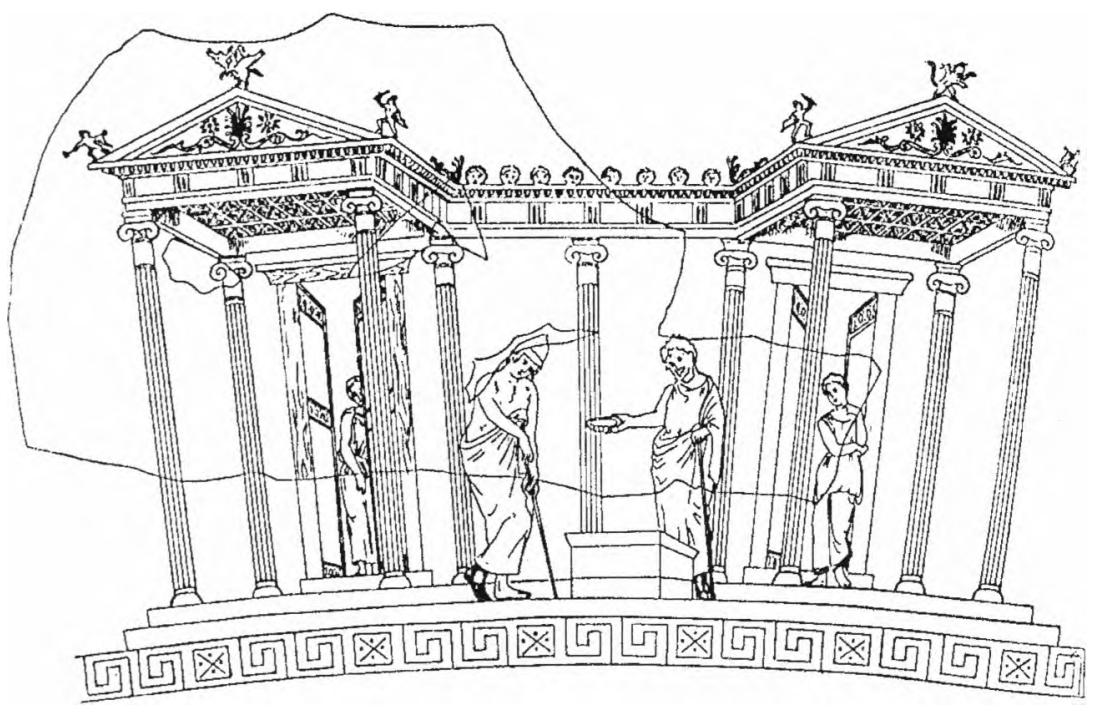

FIG. 6 - Fragmento de um calyx-krater de Tarento, em Würzburg (reconstituição)

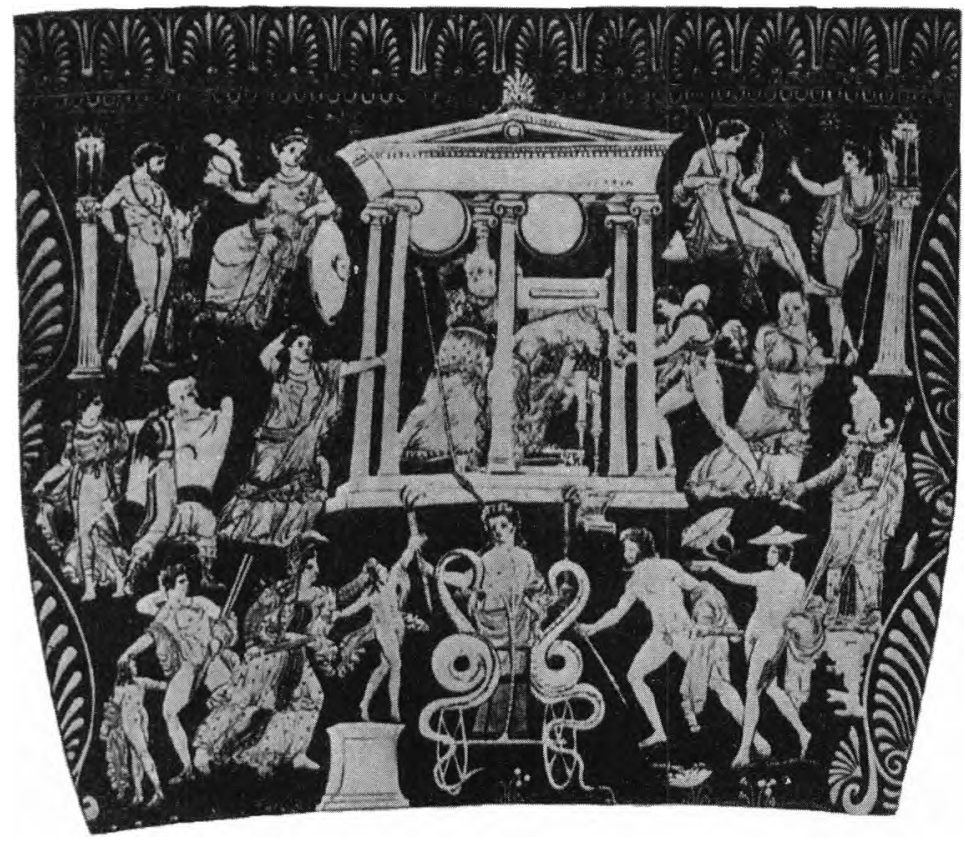

Fig. 7 - Krater-de-volutas de Canossa, em Munique. Medeia 

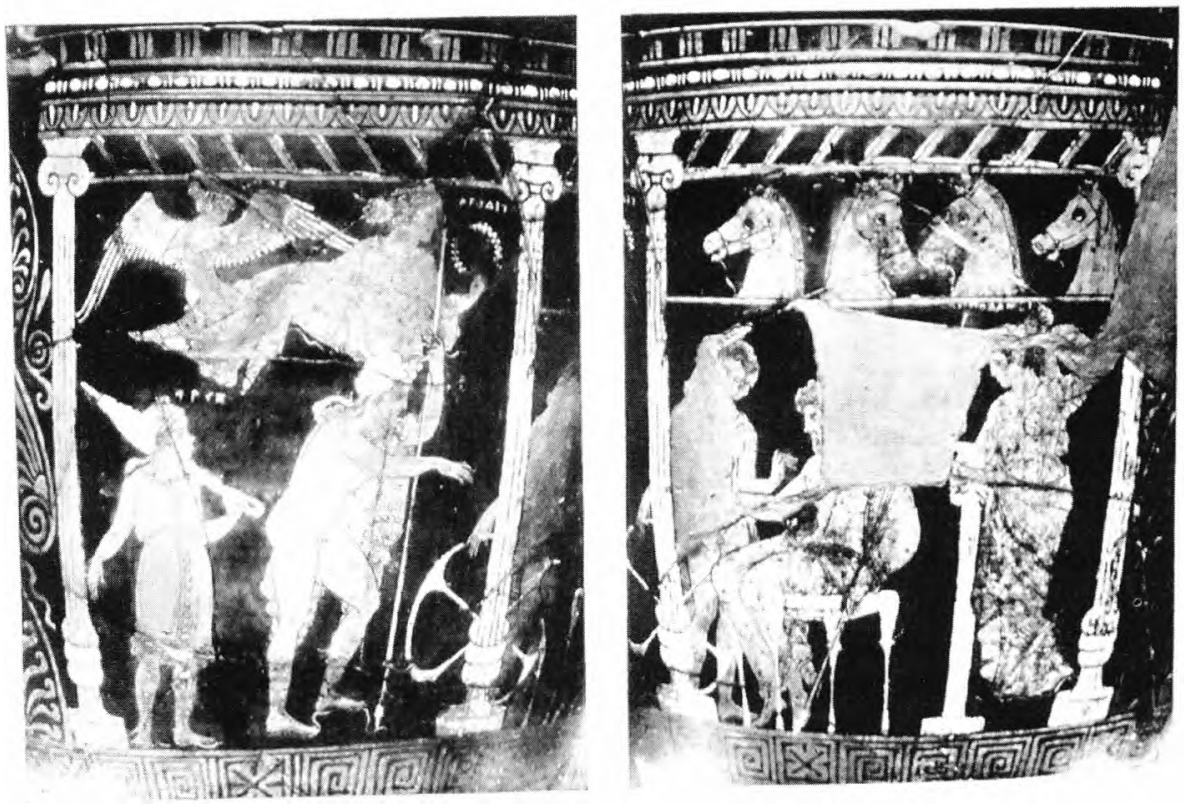

Fig. 8 - Situla em Villa Giulia. Competição entre Pélops e Enómao 


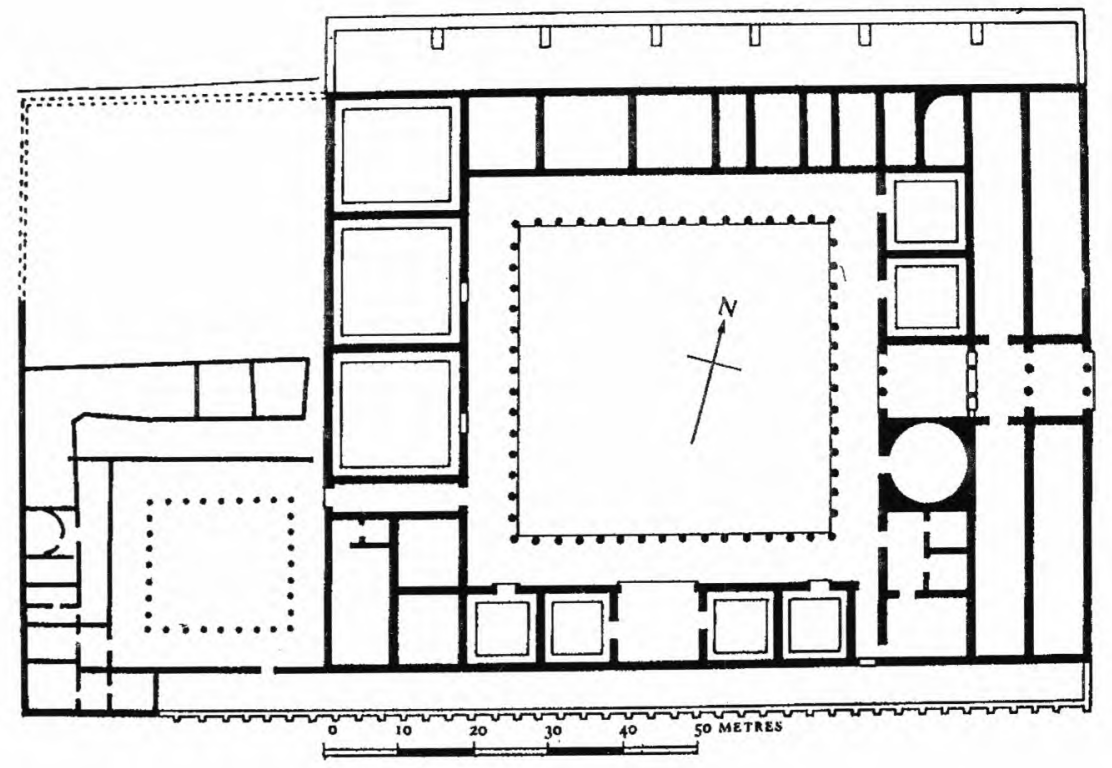

Fig. 9 - Vergina. Planta do palácio real

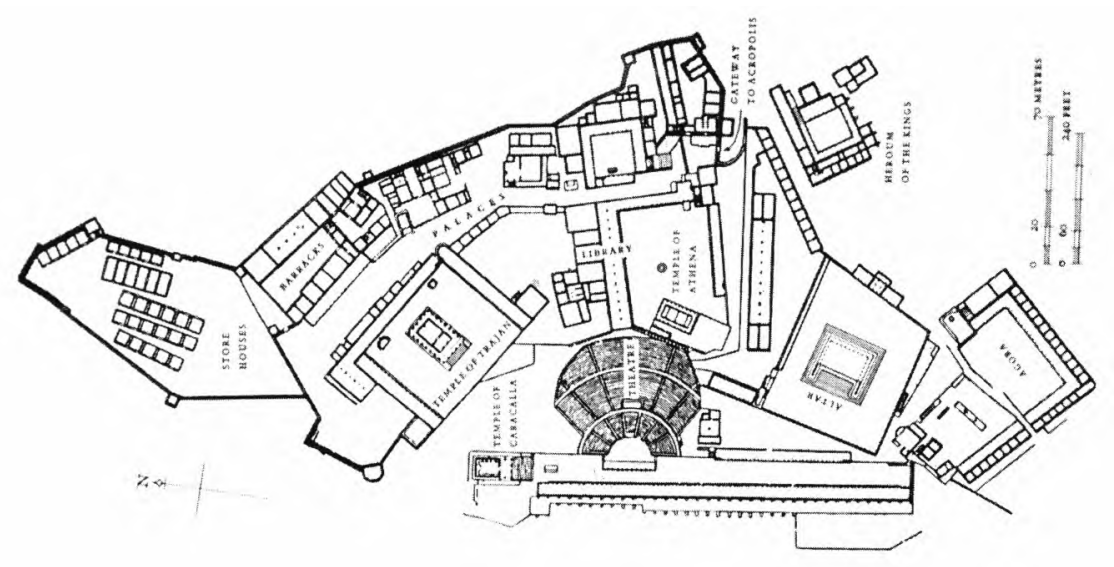

FIG. 10 - Pérgamo. Pianta da parte alta da cidade, com o palácio real e suas dependências 